\title{
Effects of dissolved mercury on embryogenesis, survival, growth and metamorphosis of Crassostrea gigas oyster larvae
}

\author{
R. Beiras ${ }^{1}$, E. His ${ }^{2}$ \\ ${ }^{1}$ Instituto Español de Oceanografía (IEO) Apdo 130, E-15080 A Coruña, Galicia, Spain \\ ${ }^{2}$ Institut Français de Recherche pour l'Exploitation de la Mer (IFREMER) Station d'Arcachon, \\ Quai du Commandant Silhouette, F-33120 Arcachon, France
}

\begin{abstract}
The effects of mercury ( $\mathrm{Hg}$ ) concentrations ranging from 0 (control) to $1024 \mu \mathrm{gl}^{-1}$ upon embryogenesis, survival, growth and metamorphosis of Crassostrea gigas (Thunberg) oyster larvae were investigated. Embryogenesis was abnormal in 50\% of the individuals at $11 \mathrm{\mu g} \mathrm{I}^{-1}$ The $48 \mathrm{~h} \mathrm{LD}_{50}$ for D-shaped, umbonate and pediveliger larvae were 33,115 and $200 \mu \mathrm{gl}^{-1}$ respectively. The increase in $\mathrm{LD}_{50}$ was partially explained by the larval weight increase, although weight-specific tolerance to $\mathrm{Hg}$ was higher in smaller larvae. Growth, the most sensitive physiological process studied, was significantly retarded at $4 \mathrm{\mu g}^{-1}$. The metamorphosis rate was significantly reduced when competent pediveligers were exposed to $64 \mathrm{\mu g} \mathrm{l}^{-1}$ for $48 \mathrm{~h}$ prior to the addition of the metamorphosis inducer epinephrine. The implications of the present results for monitoring pollution by utilising different bivalve larval stages are discussed.
\end{abstract}

KEY WORDS: Mercury $\cdot$ Oyster $\cdot$ Larva $\cdot$ Embryo $\cdot$ Bioassay $\cdot$ Ecotoxicology

\section{INTRODUCTION}

The first developmental stages of bivalves have been shown to be highly sensitive to toxicants such as pesticides (Davis \& Hidu 1969, Armstrong \& Millemann 1974, Robert et al. 1986, His \& Seaman 1993), detergents (Granmo 1972, Sigler \& Leibovitz 1982), antifouling paints (His \& Robert 1980, 1983, Laughlin et al. 1988, Lapota et al. 1993) and particularly heavy metals (Brereton et al. 1973, Calabrese et al. 1973, 1977, Calabrese \& Nelson 1974, His \& Robert 1981, 1982, Martin et al. 1981, Thain 1984). Connor (1972) found that the $\mathrm{Hg}$ concentration causing $50 \%$ mortality in Ostrea edulis L. larvae was several thousand times lower than in adults. Therefore the use of oyster embryo and larval bioassays has been proposed as a rapid and reliable method for testing the biological quality of seawater and monitoring marine pollution (His \& Robert 1986, McFadzen 1992. Thain 1992; see also Chapman \& Long 1983). These bioassays are also increasingly used for testing biological effects of polluted sediments (Chapman \& Morgan 1983; for a review see Swartz
1989). In order to assess the lethal and sublethal responses of the test individuals exposed to samples from the natural environment, a previous knowledge is needed on the effects of known levels of individual pollutants to determine which physiological processes are affected and to what extent.

Mercury has been proved to be the most toxic heavy metal for bivalve larvae (Okubo \& Okubo 1962, Calabrese et al. 1977), and also for larvae of many other marine invertebrates such as bryozoans, polychaetes, crustaceans and echinoderms (Okubo \& Okubo 1962, Wisely \& Blick 1967, Connor 1972, Johnson \& Gentile 1979, Martin et al. 1981). Its high toxicity and bioaccumulation give $\mathrm{Hg}$ a well-known ecotoxicological relevance (recently reviewed by Cossa et al. 1990) and, additionally, enables the use of relatively low, environmentally realistic doses, avoiding $\mathrm{pH}$ and solubility problems caused by other heavy metals (Wisely \& Blick 1967. Hrs-Brenko et al. 1977).

The aim of this study was to assess both the lethal (mortality) and sublethal (growth) effects of $\mathrm{Hg}$ on Crassostrea gigas (Thunberg) embryos and larvae. A 
previously unexplored sublethal response, the chemically induced metamorphosis of the pediveliger larvae, was also investigated. The implications for pollutionmonitoring bivalve bioassays are discussed in view of the results obtained.

\section{MATERIAL AND METHODS}

Experiments were conducted to study effects of dissolved $\mathrm{Hg}$ on embryogenesis, survival, growth and metamorphosis of larvae of Crassostrea gigas. Conditioned adult oysters were induced to spawn by thermal stimulation (alternating immersion in seawater at 18 and $28^{\circ} \mathrm{C}$ ) and by addition of ripe gametes in suspension. Filtered $(0.2 \mu \mathrm{m})$ natural seawater (FSW) of oceanic characteristics from the Bassin d'Arcachon, France (background $\mathrm{Hg}$ concentration $0.84 \times 10^{-3} \mu \mathrm{g}$ $\mathrm{I}^{-}$; Cossa \& Noell 1987) was used for the experiments. Eggs and sperm were suspended in sterile glass beakers and gently stirred to facilitate fertilization. After $15 \mathrm{~min}$, fertilized eggs were counted under the microscope (taking four $0.1 \mathrm{ml}$ samples from a measuring cylinder agitated with a perforated plunger) and placed into the different rearing vessels at $24 \pm 1{ }^{\circ} \mathrm{C}$.

Fresh stock solutions of $10 \mathrm{mg}$ ionic $\mathrm{Hg}^{2+} \mathrm{I}^{-1}$ were prepared from $\mathrm{HgCl}_{2}$ (analytical grade) and distilled water within $24 \mathrm{~h}$ of the start of the experiments. All glassware was acid-washed $\left(\mathrm{HNO}_{3} 10 \%\right.$ vol. $)$, rinsed with distilled water and sterilized at $170^{\circ} \mathrm{C}$ for $2 \mathrm{~h}$ before and after the experiments. An additional experiment aimed at testing the potential loss of $\mathrm{Hg}$ was conducted. Four representative $\mathrm{Hg}$ concentrations and a control were made up following the described procedures and delivered per duplicate into the same vessels used for embryogenesis and larval survival experiments. Samples were taken in sealed teflon vials and dissolved $\mathrm{Hg}$ concentration was determined at the IFREMER, Nantes, France. The analytical procedure is described elsewhere (Cossa \& Noël 1987, Gill \& Fitzgerald 1987), and includes a gold amalgamation step and detection by cold vapor atomic fluorescence. The precision and the detection limit have been estimated as $15 \%$ and 1 pM respectively. The reliability of the method has been demonstrated in intercalibration exercises (Cossa \& Courau 1990). As shown in Table 1. despite a marked loss of $\mathrm{Hg}$ at low levels, nominal and determined concentrations agreed well within the range of $\mathrm{Hg}$ levels which were found toxic for both embryos and larvae (see 'Results').

Embryogenesis. A total of 600 fertilized eggs were transferred to $25 \mathrm{ml}$ polyethylene Coulter Counter accuvettes (4 or 5 replicates per treatment) and incubated at $24 \pm 1^{\circ} \mathrm{C}$ for $24 \mathrm{~h}$ in the presence of the following nominal $\mathrm{Hg}$ concentrations: 0 (controls), 1, 2, 4 ,
Table 1. Gravimetrically measured $\mathrm{Hg}$ concentrations added to water (nominal concentrations) and $\mathrm{Hg}$ concentrations determined by chemical analysis of experimental seawater samples (determined concentrations, mean $\pm \mathrm{SE}$ )

\begin{tabular}{|cc|}
\hline $\begin{array}{c}\text { Nominal Hg conc. } \\
\left(\mu \mathrm{I} \mathrm{l}^{-1}\right)\end{array}$ & $\begin{array}{c}\text { Determined Hg conc. } \\
\left(\mu g \mathrm{I}^{-1}\right)\end{array}$ \\
\hline 0 & $<0.01^{\mathrm{d}}$ \\
2 & $0.3 \pm 0.07$ \\
8 & $3.6 \pm 0.16$ \\
32 & $27.9 \pm 0.28$ \\
128 & $111 \pm 21.2$ \\
a Below detection limit & \\
\hline
\end{tabular}

$8,16,32,64 \mu \mathrm{g} \mathrm{l}^{-1}$. After incubation, $100 \mu \mathrm{l}$ of $4 \%$ buffered formalin was added to each accuvette and 200 individuals per accuvette were observed under Olympus CK inverted microscopes in order to record the number of abnormal larvae. Therefore, no handling or sieving was needed. The Hg concentration that caused $50 \%$ abnormalities, $\mathrm{AD}_{50}$, was calculated using the logprobit method (Hayes 1991), plotting the logprobit-converted percentages of mortality inferior and superior to $50 \%$ as a function of the $\mathrm{Hg}$ doses in logarithmic (base 2) scale.

Larval survival. In order to obtain the larvae at different developmental stages for the survival experiments, fertilized eggs were placed into beakers containing $3 \mathrm{l}$ of clean FSW and incubated at $24 \pm 1^{\circ} \mathrm{C}$ for $24 \mathrm{~h}$. Larvae were then reared at 10 larvae $\mathrm{ml}^{-1}$ on a mixed diet of 100 cells $\mu \mathrm{l}^{-1} \mathrm{~d}^{-1}$ of the microalgae Isochrysis galbana and Chaetoceros calcitrans forma pumilum (50:50). Water was changed every $2 \mathrm{~d}$ until the pediveliger stage, by sieving the larvae with screens of $40 \mu \mathrm{m}$ mesh. In order to prevent bacterial proliferation, all material in contact with the larvae was routinely washed with hypochlorite and hot water, and sterilized at $170^{\circ} \mathrm{C}$ for $2 \mathrm{~h}$.

The experiments to determine survival were conducted when larvae reached the D-shaped, umbonate and pediveliger stages, using the accuvettes methodology described for embryos (no food added), except that exposure time was $48 \mathrm{~h}$ in order to allow a more obvious discrimination between dead and live larvae. $\mathrm{Hg}$ concentrations tested ranged from 1 to $512 \mu \mathrm{g} \mathrm{l}^{-1}$ increasing in a $\log _{2}$ scale, plus a control. The $\mathrm{Hg}$ concentration that caused $50 \%$ mortality, $L D_{50}$, was calculated as described for the $A D_{50}$. In the umbonate and pediveliger larvae experiments, the accuvettes were also microscopically observed after 24 and $48 \mathrm{~h}$ prior to formalin addition, in order to record larval appearance and swimming behaviour in vivo. For each developmental stage, larval size (height) was measured on a sample $(n=50)$ using a microscope $(100 \times$ or $200 \times$ mag- 
nification) with a graduated eye-piece. Larval ash-free dry weight (AFDW) was estimated from the heightAFDW relationship determined by His \& Maurer (1988) for Crassostrea gigas larvae.

Growth. Duplicated samples of fertilized eggs $(8000$ $\left.1^{-1}\right)$ were reared at $24 \pm 1^{\circ} \mathrm{C}$ in 21 hard-glass vessels, and continuously exposed to 0 (controls), 1, 2, 4 or $8 \mu \mathrm{g}$ $\mathrm{Hg} \mathrm{l}^{-1}$ during embryogenesis and larval development. Larvae were fed as indicated above. Changes of FSW and larval sampling were carried out on Days 1, 2, 4, 6 , 8 and 10 . The samples were photographed with a Canon camera fitted to an inverted microscope in order to subsequently record the mean height using the negatives and a binocular microscope with a graduated eyepiece. With this aim, photographs of a $0.01 \mathrm{~mm}$ graticule were also taken. Regression lines were fitted to the larval growth data and slopes were compared by analysis of covariance, performed according to Sokal \& Rohlf (1981).

Metamorphosis. Experiments were carried out when pediveligers where ready (competent) to metamorphose, as indicated by larval size $>290 \mu \mathrm{m}$ and a high percentage of eyed larvae. Larvae $\left(11 \mathrm{ml}^{-1}\right)$ were delivered in $3 \mathrm{ml}$ Nunclon tissue-culture microwells filled with FSW at the different $\mathrm{Hg}$ concentrations (4 or 8 replicates per treatment). Metamorphosis was induced by using epinephrine (Sigma) from a freshly made stock $10^{-2} \mathrm{M}$ in distilled water, added to a final concentration in the wells of $10^{-4} \mathrm{M}$. Two experiments were carried out. In the first, the inductor was added at time 0 , and in the second, the inductor was added at time $48 \mathrm{~h}$. The number of postlarvae was recorded $2 \mathrm{~d}$ after the addition of the inductor by means of the inverted microscope. Homogeneous groups of means not significantly different for a confidence level $\mathrm{p}<$
0.05 were detected by applying the Fisher PLSD test (Statview computer software). Proportion of metamorphosed individuals was the variable statistically analysed after arcsine of the square root transformation. Means and standard error were back-transformed for presentation.

\section{RESULTS}

\section{Embryogenesis and larval survival}

The effects of different $\mathrm{Hg}$ concentrations on embryogenesis and larval survival are presented in Table 2. A consistent increase in tolerance to $\mathrm{Hg}$ with age was noted. The $\mathrm{AD}_{50}$ or $\mathrm{LD}_{50}$ were $13,33,115$ and $200 \mathrm{~g} \mathrm{Hg} \mathrm{l}^{-1}$ for embryos, D-shaped larvae, umbonate larvae and pediveliger larvae respectively (see sizes in Table 2). This increase in $\mathrm{Hg}$ tolerance was further investigated by plotting the $\mathrm{LD}_{50}$ as a function of weight (AFDW, ng) (Fig. 1). The effect of $\mathrm{Hg}$, measured by the $\mathrm{LD}_{50}$, was an allometric function of larval size following the equation (SE of the fitting parameters are given in parentheses):

$$
\begin{gathered}
\operatorname{lnLD} 50=1.993( \pm 0.0181)+0.460( \pm 0.0032) \ln \text { AFDW }, \\
\mathrm{r}=0.999, \mathrm{p}=0.004 .
\end{gathered}
$$

A sublethal effect, the inhibition of swimming, was observed in vivo (Table 2), and occurred at Hg nominal concentrations -30 times lower than those causing lethal effects. Observations were also made of static larvae, apparently unable to withdraw the velum. In the more toxic treatments $\left(128,256\right.$ and $\left.512 \mu \mathrm{g} \mathrm{l}^{-1}\right)$ dead larvae presented extruded and granulated tissues, with the appearance of 'exploded' larvae.

Table 2. Crassostrea gigas. Abnormalities for embryos (2 experiments) and mortality for larvae exposed to different Hg concentrations for 24 (embryos) or $48 \mathrm{~h}$ (larvae). Values presented are mean percentage $\pm \mathrm{SE}$. Height (mean $\pm \mathrm{SD}$ ) of larvae is also shown. For umbonate larvae and pediveligers, swimming activity was classified arbitrarily as normal, low (when at least $50 \%$

\begin{tabular}{|c|c|c|c|c|c|c|c|c|c|c|c|}
\hline \multicolumn{5}{|l|}{ Stage } & \multicolumn{7}{|c|}{ Abnormalities or mortality (\%) } \\
\hline $\mathrm{Hg}\left(\mu \mathrm{gl}^{-1}\right)$ & 0 & 1 & 2 & 4 & 8 & 16 & 32 & 64 & 128 & 256 & 512 \\
\hline Embryos & $5.2 \pm 1.58$ & $2.6 \pm 0.59$ & $3.5 \pm 1.00$ & $2.5 \pm 0.46$ & $39.8 \pm 7.5$ & $63.8 \pm 10.7$ & 100 & 100 & $\mathrm{~nm}$ & $\mathrm{~nm}$ & $\mathrm{~nm}$ \\
\hline $\begin{array}{l}\text { D-shaped } \\
(68.1 \pm 2.45 \mu \mathrm{m})\end{array}$ & 0 & $0.5 \pm 0.29$ & $0.2 \pm 0.25$ & 0 & $0.4 \pm 0.24$ & $0.7 \pm 0.90$ & $46.0 \pm 21.1$ & $96.6 \pm 1.75$ & $\mathrm{~nm}$ & $\mathrm{~nm}$ & $\mathrm{~nm}$ \\
\hline $\begin{array}{l}\text { Umbonate } \\
(211 \pm 22.0 \mu \mathrm{m})\end{array}$ & $\begin{array}{l}2.3 \pm 0.53 \\
\text { Normal }\end{array}$ & $\mathrm{nm}$ & $\begin{array}{l}1.5 \pm 0.47 \\
\text { Normal }\end{array}$ & $\begin{array}{l}1.1 \pm 0.29 \\
\text { Normal }\end{array}$ & $\begin{array}{c}1.7 \pm 0.62 \\
\text { Low }\end{array}$ & $\begin{array}{c}6.4 \pm 0.61 \\
\text { Low }\end{array}$ & $\begin{array}{c}3.6 \pm 2.07 \\
\text { Low }\end{array}$ & $\begin{array}{c}2.3 \pm 1.18 \\
\text { Null }\end{array}$ & $\begin{array}{c}63.0 \pm 4.56 \\
\text { Null }^{b}\end{array}$ & $\mathrm{~nm}$ & $\mathrm{~nm}$ \\
\hline $\begin{array}{l}\text { Pediveliger } \\
(310 \pm 22.7 \mu \mathrm{m})\end{array}$ & $\begin{array}{c}3.6 \pm 0.43 \\
\text { Normal }\end{array}$ & $\mathrm{nm}$ & $\mathrm{nm}$ & $\mathrm{nm}$ & $\begin{array}{l}3.6 \pm 0.92 \\
\text { Normal }\end{array}$ & $\begin{array}{c}3.8 \pm 0.34 \\
\text { Low }\end{array}$ & $\begin{array}{c}2.8 \pm 0.63 \\
\text { Null }\end{array}$ & $\begin{array}{l}2.7 \pm 0.43 \\
\text { Null }\end{array}$ & $\begin{array}{r}5.7 \pm 1.38 \\
\text { Null }^{\mathrm{a} b \mathrm{~b}}\end{array}$ & $\begin{array}{c}81.3 \pm 2.27 \\
\text { Null }^{b}\end{array}$ & $\begin{array}{c}96.6 \pm 0.84 \\
\text { Null }^{\mathrm{b}}\end{array}$ \\
\hline
\end{tabular}
of the individuals were static) or null. nm: not measured 


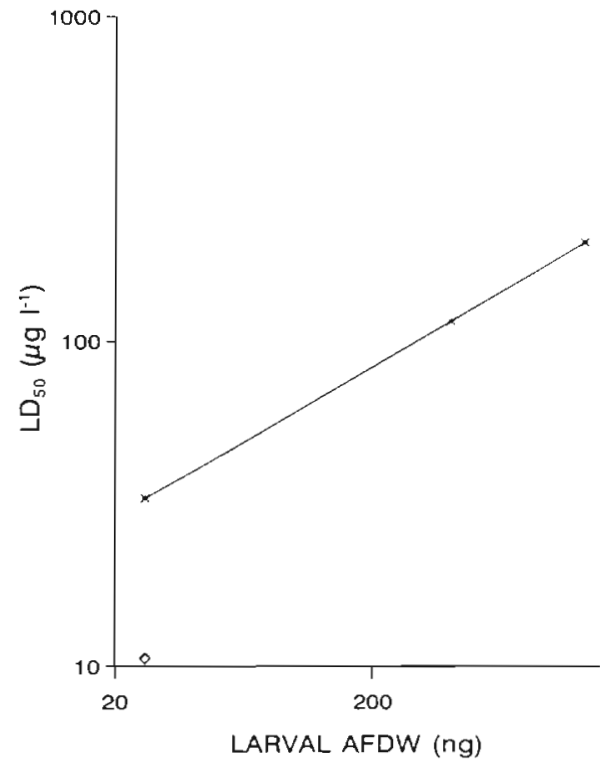

Fig. 1 Crassostrea gigas. Double logarithmic plot relating $\mathrm{Hg}$ dose causing $50 \%$ larval mortality after $48 \mathrm{~h}\left(\mathrm{LD}_{50}\right)$ to larval ash-free dry weight (AFDW). $(\diamond) \mathrm{Hg}$ dose causing $50 \%$ abnormalities in embryogenesis $\left(\mathrm{AD}_{50}\right)$ assuming no $\mathrm{AFDW}$ change during the endotrophic development

\section{Growth}

Shell height increase is presented in Fig. 2 for the different $\mathrm{Hg}$ concentrations. A reduction in growth rate is evident in the larvae exposed to 4 and $8 \mu \mathrm{g} \mathrm{l}^{-1}$ from Day 6. Sensitivity of larval growth to $\mathrm{Hg}$ was probably underestimated in this experiment, taking into account the loss of $\mathrm{Hg}$ in the experimental vessels detected at low levels of toxicant (Table 1). Growth retardation was further investigated by fitting straight lines and comparing their slopes. This does not imply that height increase was strictly linear in our experiment. Since toxicity is directly related to exposure time (Hayes 1991), deviations from linear growth are expected in the long term at the effective $\mathrm{Hg}$ concentrations. This is in good agreement with our data shown in Fig. 2 at $8 \mu \mathrm{g} \mathrm{Hg} \mathrm{l}^{-1}$. Moreover, a plateau appears to be reached the last $2 \mathrm{~d}$ of experiment by the larvae exposed to the highest toxic concentration. An analysis of covariance detected highly significant differences among slopes $(F=29.6, \mathrm{df}=4,20, \mathrm{p}<0.01)$. These slopes, equivalent to the growth rate, were inversely related to $\mathrm{Hg}$ concentration (Fig. 3) following the regression model:

$$
\begin{gathered}
G R=13.14( \pm 0.294)-0.92( \pm 0.071) C \\
r=-0.991, p=0.001
\end{gathered}
$$

where $G R$ is the growth rate $\left(\mu \mathrm{m} \mathrm{d}^{-1}\right), C$ is the Hg concentration ( $\mathrm{g}^{-1}$ ), and $\mathrm{SE}$ of the fitting parameters are shown in parentheses.

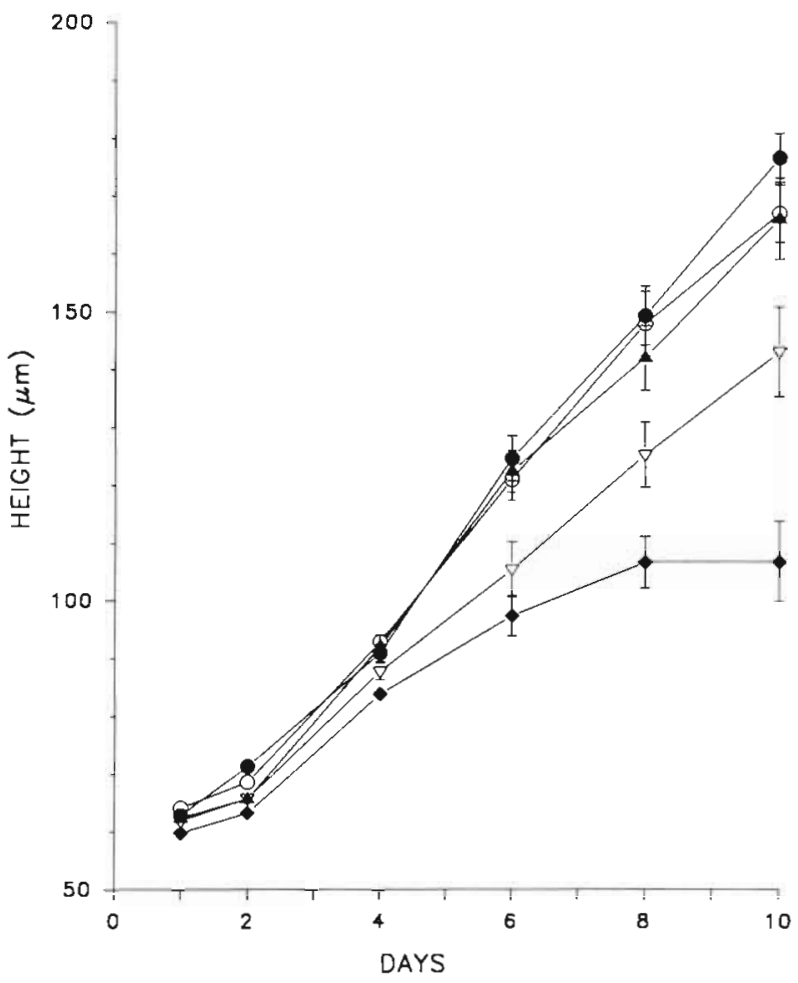

Fig. 2. Crassostrea gigas. Height increase in larvae reared from D-shaped stage at $0(\bullet), 1(0), 2(\Delta), 4(\nabla)$ and $8(\bullet$ $\mu \mathrm{g} \mathrm{Hg} \mathrm{l^{-1 }}$ over $10 \mathrm{~d}$. Error bars are $\pm \mathrm{SE}$

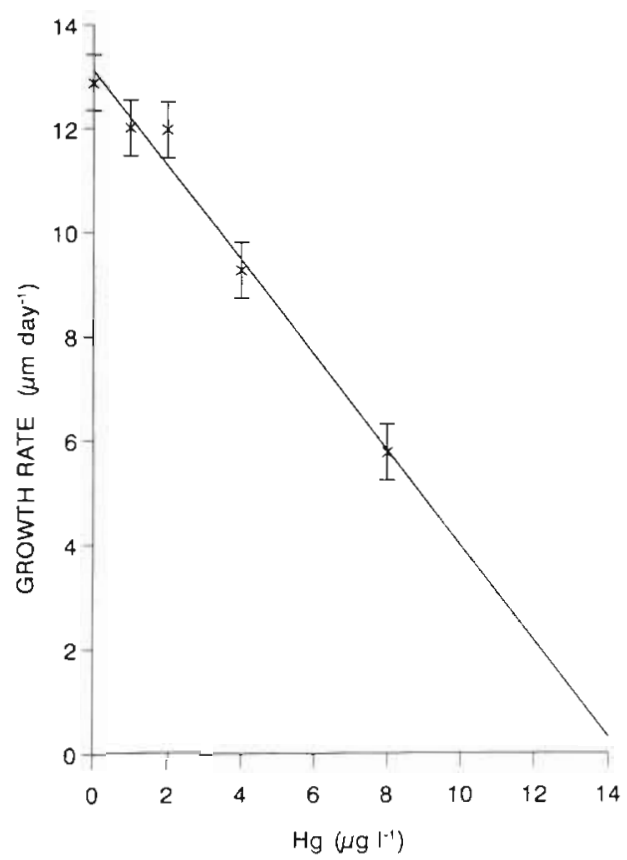

Fig. 3. Crassostrea gigas. Inverse relationship between growth rate and $\mathrm{Hg}$ dose in larvae reared from $\mathrm{D}$-shaped stage at different mercury concentrations over $10 \mathrm{~d}$. Error bars are $\pm \mathrm{SE}$ 
Table 3. Crassostrea gigas. Effect of different Hg concentrations on the percentage of postlarvae (mean \pm SE) using the metamorphosis inducer epinephrine $\left(10^{-4} \mathrm{M}\right)$. In Expt 1, epinephrine and Hg were synchronously added $(t=0 \mathrm{~h})$, and in Expt 2, epinephrine was added at $t=48 \mathrm{~h}$. Height (mean $\pm \mathrm{SD}$ ) of larvae is also shown. Within experiments, means with the same superscript are not significantly different $(p<0.05)$. nm: not measured

\begin{tabular}{|c|c|c|c|c|c|c|c|c|c|c|c|c|}
\hline \multirow[b]{2}{*}{$\left.\mathrm{Hg}(\mu g]^{-1}\right):$} & \multicolumn{12}{|c|}{ Metamorphosis (\%) } \\
\hline & 0 & 1 & 2 & 4 & 8 & 16 & 32 & 64 & 128 & 256 & 512 & 1024 \\
\hline \multicolumn{13}{|c|}{ Expt $1(314 \pm 10.9 \mu \mathrm{m})$} \\
\hline & $56.9^{4}$ & $48.8^{\mathrm{A}}$ & $46.0^{\mathrm{A}}$ & $42.5^{\mathrm{A}}$ & $40.8^{\mathrm{A}}$ & $44.0^{\mathrm{A}}$ & $42.3^{\mathrm{A}}$ & $46.4^{\mathrm{A}}$ & $36.2^{\mathrm{A}}$ & $12.8^{\mathrm{B}}$ & $1.4^{\mathrm{C}}$ & $\mathrm{nm}$ \\
\hline & \pm 1.89 & \pm 0.12 & \pm 0.50 & \pm 0.10 & \pm 0.28 & \pm 0.14 & \pm 0.75 & \pm 0.43 & \pm 1.50 & \pm 0.40 & \pm 0.20 & \\
\hline $\begin{array}{l}\text { Control without } \\
\text { epinephrine }\end{array}$ & $\begin{aligned} & 1.3^{\mathrm{C}} \\
\pm & 0.49\end{aligned}$ & & & & & & & & & & & \\
\hline \multicolumn{13}{|c|}{ Expt $2(297 \pm 21.5 \mu \mathrm{m})$} \\
\hline$t=48 \mathrm{~h}$ & $\begin{array}{l}0.9 \\
\pm 0.14\end{array}$ & 0 & 0 & 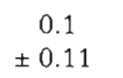 & $\begin{aligned} & 0.3 \\
\pm & 0.12\end{aligned}$ & $\begin{array}{ll} & 1.0 \\
\pm & 0.15\end{array}$ & $\begin{aligned} & 1.9 \\
\pm & 0.13\end{aligned}$ & $\begin{array}{l}1.1 \\
\pm 0.27\end{array}$ & $\begin{array}{l}0.2 \\
\pm \\
0.08\end{array}$ & $\begin{array}{l}0.1 \\
\pm \\
0.07\end{array}$ & 0 & 0 \\
\hline \multirow[t]{2}{*}{$t=96 \mathrm{~h}$} & $9.5^{\mathrm{A}}$ & $13.9^{A}$ & $7.3^{A}$ & $5.1^{\mathrm{A}, \mathrm{B}}$ & $4.3^{\mathrm{A}, \mathrm{B}}$ & $5.3^{\mathrm{A}, \mathrm{B}}$ & $4.8^{\mathrm{A} \cdot \mathrm{B}}$ & $1.9^{B, C}$ & $0.2^{C \cdot D}$ & $0^{\mathrm{D}}$ & $0^{\mathrm{D}}$ & $0^{\mathrm{D}}$ \\
\hline & \pm 0.23 & \pm 0.20 & \pm 0.34 & \pm 0.26 & \pm 0.26 & \pm 0.21 & \pm 0.18 & \pm 0.42 & \pm 0.11 & & & \\
\hline
\end{tabular}

\section{Metamorphosis}

The percentages of metamorphosed individuals obtained in competent pediveligers exposed to different $\mathrm{Hg}$ concentrations are presented in Table 3. In Expt 1, where the $\mathrm{Hg}$ and the metamorphosis inducer epinephrine $\left(10^{-4} \mathrm{M}\right)$ were added synchronously, no

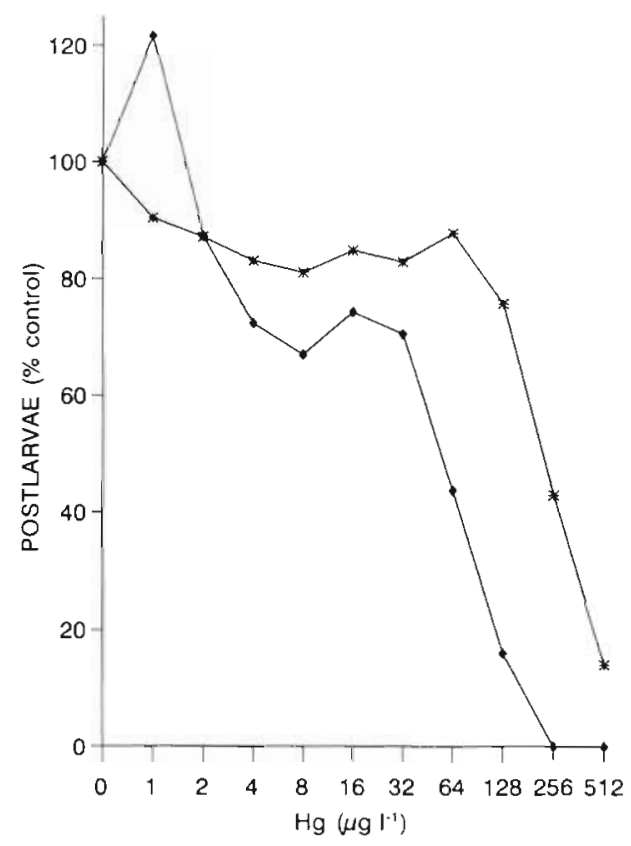

Fig. 4. Crassostrea gigas. Postlarvae developed 2 d after the addition of the metamorphosis inducer epinephrine, expressed as a percentage of the respective controls, and plotted against $\mathrm{Hg}$ concentration. (*) Epinephrine and $\mathrm{Hg}$ synchronously added $(\bullet)$ epinephrine added $48 \mathrm{~h}$ after $\mathrm{Hg}$ significant toxic effects were found until $\mathrm{Hg}$ concentrations as high as $256 \mathrm{ug} \mathrm{l}^{-1}$, which reduced the percentage of postlarvae to approximately one-fourth that of the controls due to lethal effects on the pediveligers. In contrast, sublethal effects were found in Expt 2, where larvae were exposed to the toxicant for $48 \mathrm{~h}$ before the inducer; a significant decrease in metamorphosis was detected at $64 \mathrm{\mu g} \mathrm{l}^{-1}$, and negligible percentages of postlarvae were observed at $\mathrm{Hg}$ concentrations equal to or higher than $128 \mu \mathrm{g} \mathrm{l}^{-1}$. The proportion of postlarvae obtained $2 \mathrm{~d}$ after the inducer addition in both experiments were expressed as percentages of the respective controls for comparison and plotted against Hg concentration (Fig. 4). Pediveligers were more sensitive to toxic effects inhibiting metamorphosis when exposed to $\mathrm{Hg} 48 \mathrm{~h}$ before the addition of epinephrine. In this case, enhanced average metamorphosis was also observed at the minimum toxic level (hormesis), although this result did not reach statistical significance.

\section{DISCUSSION}

\section{Embryogenesis and larval survival}

For comparison of $\mathrm{LD}_{50}$ values among experiments, the exposure period should be taken into account, since the duration of dosing is a major factor influencing toxicity (see review by Hayes 1991). For example, in Daphnia pulex, Tian-yi \& McNaught (1992) reported $\mathrm{LD}_{50}$ values of $31.2,5.7$ and $1.8 \mu \mathrm{g} \mathrm{l}^{-1}$ methylmercury for exposure times of 24,48 and $96 \mathrm{~h}$ respectively. The $\mathrm{AD}_{50}$ values found in the present study for embryos $\left(11 \mu \mathrm{g} \mathrm{l}^{-1}\right)$ and the $\mathrm{LD}_{50}$ for $\mathrm{D}$ - 


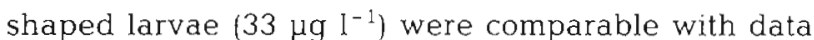
from the literature for oyster species, most of them referred to exposure times of 24 to $48 \mathrm{~h}$. For embryos, $\mathrm{AD}_{50}$ 's (frequently regarded as $\mathrm{EC}_{50}$ 's) were 10 to $32 \mathrm{\mu g} \mathrm{l}^{-1}$ (Okubo \& Okubo 1962), 4.2 to $6.8 \mathrm{\mu g} \mathrm{l}^{-1}$ (Calabrese et al. 1973) and $6.7 \mathrm{\mu g} \mathrm{l}^{-1}$ (Martin et al. 1981). For larvae, $L D_{50}$ 's previously found were 10 to $32 \mathrm{\mu g} \mathrm{l}^{-1}$ (Okubo \& Okubo 1962) and 1 to $3 \mu \mathrm{g} \mathrm{l}^{-1}$ (Connor 1972). Calabrese et al. (1977) exposed Crassostrea virginica larvae to $\mathrm{Hg}$ for $12 \mathrm{~d}$ and found an $\mathrm{LD}_{50}$ of $12 \mu \mathrm{g} \mathrm{l}^{-1}$. Similar values have also been reported for crustacean larvae: 10 to $33 \mu \mathrm{g} \mathrm{l}^{-1}$ (Connor 1972, Shealey \& Sandifer 1975). We found in this study that some of the variability in larval sensitivity to toxics previously reported can be explained by the effect of size. However, after expressing the toxic amount as dosage (per unit weight), changes in sensitivity during the ontogenic development in the present study are still apparent. The $\mathrm{LD}_{50}$ vs AFDW allometric relationship showed an exponent $b<1(b=$ 0.46 ), indicating that $\mathrm{LD}_{50}$ per unit weight is lower in larger larvae; i.e. there is a relatively higher sensitivity to $\mathrm{Hg}$ in more advanced stages. When expressed as weight specific dosage, $\left(\mu \mathrm{g} \mathrm{l}^{-1} \mathrm{ng}^{-1}\right.$ AFDW), LD $\mathrm{D}_{50}$ decreases gradually from 1.27 in D-shaped larvae to 0.15 in pediveligers.

Much controversy has arisen regarding whether bivalve embryos are more sensitive to toxicants than larvae. Concerning metal toxicity, Okubo \& Okubo (1962) and Watling (1982) found higher toler ance in embryos. In contrast, this study supports those from Calabrese et al. (1977) and His \& Robert (1982), stating that bivalve embryos are more sensitive to metal pollutants than later larval stages. Piyan et al. (1985) and Wong et al. (1993) also found that tolerance to heavy metals increased with age in crustacean larvae. Assessing the toxicity of several pesticides on early phases of oyster development, Davis \& Hidu (1969) reported that the $A D_{50}$ or $L D_{50}$ values were higher for larvae in 10 cases, higher for embryos in 8 cases and similar in 6 cases. At least part of this controversy can be explained when exposure times are considered. Davis \& Hidu (1969) exposed embryos to the toxicant for $48 \mathrm{~h}$, whilst larvae were exposed for $14 \mathrm{~d}$. Exposure times were also markedly longer for larvae in Watling's (1982) study, and the results compared were obtained in independent experiments, as in the case of Calabrese et al. (1977). Hrs-Brenko et al. (1977) demonstrated that the sensitivity of embryos to lead is affected by environmental conditions, namely temperature and salinity, and Nelson et al. (1977) found enhanced toxicity of $\mathrm{Hg}$ at high temperatures and low salinities for Argopecten irradians juveniles. Therefore, these factors should be standardized to enable comparisons between experiments. In the present study exposure periods for embryo and larvae were comparable (although still longer for larvae), lethal effects were measured under exactly the same experimental parameters (e.g. temperature, salinity, water quality), and no algal food was present in the medium. In these conditions, the D-shaped larvae showed a 3 times enhanced $\mathrm{LD}_{50}$ compared to embryos. Those requirements for comparison were also met in the study by Roberts (1987), who also found a 3 times enhanced $L D_{50}$ for tributyltin (TBT) in both oyster and clam D-shaped larvae compared to their embryos. Similarly, toxicity of an insecticide (Sevin) decreased in later stages of the embryogenesis for mussel (Armstrong \& Millemann 1974).

Enhanced larval resistance cannot be explained by difference in weight since no biomass increase is expected during the endotrophic development (fueled by endogenous reserves only). One of the major events during this step in the embryogenesis of bivalves is the development of the larval shell (prodissoconch). Valve closure is a well-known protective mechanism against environmental stress in adult molluscs (reviewed by Akberali \& Trueman 1985). Rapid shell closure in response to toxics has also been recorded by previous workers for larvae (Wisely \& Blick 1967). In the present study, partial and total inhibition of swimming was also observed (Table 2). Moreover, at high $\mathrm{Hg}$ concentrations (though sublethal for the present exposure time), larvae have been observed to be static, with the velum protruded, apparently trapped by a rapid shell closure. Comparable observations of protruded foot have been made by Wisely \& Blick (1967) on bivalve early postlarvae. We have also recorded the presence of isolated velums at the highest $\mathrm{Hg}$ concentrations. Withdrawal into their shell is likely a mechanism that may account for the short-term higher resistance of larvae to chemical stress, compared to embryos. In this context, Piyan et al. (1985) have suggested that increased tolerance to $\mathrm{Hg}$ in older stages of prawn larvae may be due to their thicker cuticle.

In conclusion, it is apparent from this and other studies that embryos are preferable for acute bioassay tests due to (1) higher sensitivity to metal pollutants, (2) more rapid and simple evaluation of the lethal effects of the pollutant, and (3) more simple standardization of the bioassay, avoiding interference of variables such as larval age, larval condition and presence of algal food.

Although larval behavioural responses were not strictly quantified in the present study, we have observed marked inhibition of swimming at $\mathrm{Hg}$ concentrations 16 times lower than those proved to be lethal. This experimental evidence leads us to suggest the potential use of those responses as a more sensitive index of chemical stress. 


\section{Growth}

Experimental evidence shown in this study indicates that larval growth is reduced at lower metal concentrations than those reducing survival. At a nominal concentration of $4 \mu \mathrm{g} \mathrm{Hg} \mathrm{^{-1 }}$, growth rate decreased by a factor of 0.7 , and at $8 \mu \mathrm{g} \mathrm{l}^{-1}$ by a factor of 0.4 , whilst effects on acute mortality were not apparent until $32 \mu \mathrm{g} \mathrm{I}^{-1}$. Calabrese \& Davis (1970, cited by Watling 1982) stated that a marked reduction in the growth of bivalve larvae was in general the first indication of heavy metal toxicity. Walne (1970) showed that sublethal concentrations of Zn could reduce oyster larval growth. Davis \& Hidu (1969) also found that larval growth was retarded in general at lower concentrations of pesticides than those enhancing larval mortality. A $5 \mathrm{~d}$ exposure to $150 \mu \mathrm{g} \mathrm{l}^{-1} \mathrm{Zn}$ reduced growth by approximately $50 \%$ over $10 \mathrm{~d}$ in Crassostrea gigas larvae, whilst $\mathrm{LD}_{50}$ for embryos was $250 \mathrm{Kg} \mathrm{l}^{-1}$ (Brereton et al. 1973). Similarly, hatching success in fish embryos has been found to be 2 times more sensitive to $\mathrm{Hg}$ than the $\mathrm{LD}_{50}$ (Sharp \& Neff 1980), Watling (1982) found for oyster larvae metal concentrations causing a $50 \%$ reduction in growth $\left(\mathrm{GD}_{50}\right)$ consistently lower than both embryo and larval $\mathrm{LD}_{50}$, and Wiederholm et al. (1987) observed that growth and reproduction of freshwater oligochaetes were generally affected earlier than survival, by sediments polluted by heavy metals.

For any given physiological rate, acute effects are caused by toxicant concentrations higher than those causing chronic effects (reviewed by Amiard-Triquet 1983). For example, in Mytilus edulis larvae, a $48 \mathrm{~h}$ $\mathrm{LD}_{50}$ of $2.3 \mu \mathrm{g} \mathrm{l}^{-1} \mathrm{TBT}$ has been reported by Thain (1983) but a $15 \mathrm{~d}$ LD $_{50}$ of only $0.1 \mu \mathrm{g} \mathrm{l^{-1 }}$ TBT by Beaumont \& Budd (1984). However, higher sensitivity of sublethal responses is not only due to longer exposure times. Mercury-induced $L_{50}$ decreases with exposure time up to 2 to $3 \mathrm{~d}$, but becomes constant at longer exposure periods (for juvenile bivalves, Nelson et al. 1976; for fish embryos, Sharp \& Neff 1980; see also review in Cossa et al. 1990). In contrast, growth inhibition is progressively stronger during more than $1 \mathrm{wk}$ of chronic exposure (present study).

A retardation of growth, prolonging the pelagic larval life at environmentally realistic heavy metal concentrations, will have obvious ecological implications on the recruitment of these bivalves (Calabrese et al. 1973). Concerning larval bioassays, it can be concluded that larval growth is a more sensitive physiological response than survival, and in spite of demanding longer-term trials, more useful for a realistic assessment of the impact of a potential pollutant on the wild.

\section{Metamorphosis}

This study reports sublethal effects of $\mathrm{Hg}$ causing a $50 \%$ decrease in the chemically induced metamorphic rate $\left(\mathrm{MD}_{50}\right)$ at concentrations $\sim 60 \mu \mathrm{g} \mathrm{l}^{-1}$ We could not find previous data in the literature for comparison. Phelps \& Warner (1990) stated that metamorphosis failure is a valid bioindicator of general toxicity and proposed its use for sediment bioassays. They found that chemically induced metamorphosis was completely inhibited in the presence of copper-enriched sediment. Some evidence is presented in this study suggesting that, at least for liquid-phase bioassays, metamorphosis failure may not be such a sensitive indicator of toxicity. The addition of a chemical inducer of metamorphosis such as epinephrine (Coon et al. 1986) contributes to a marked increase and standardisation in the otherwise unpredictable metamorphic rates, enabling statistical comparisons. The strong effect of epinephrine on competent pediveligers completely masked any potential sublethal effect of $\mathrm{Hg}$ on this physiological parameter when the inducer and the metal were synchronously added. This forced us to run the second experiment, where $\mathrm{Hg}$ was added $48 \mathrm{~h}$ earlier, enabling a potential inhibitory effect to act without interaction with the epinephrine induction. However, as a result, larvae underwent 2 additional days of starvation, which is likely to partially account for the uniformly lower metamorphosis percentages achieved in this second experiment (Table 3). Clearly further research is needed to clarify whether metamorphosis inhibition is a potentially useful physiological response in toxicological studies.

Average metamorphic rate was increased to more than $120 \%$ at sublethal $\mathrm{Hg}^{2+}$ nominal concentrations $\left(1 \mathrm{\mu g} \mathrm{l}^{-1}\right.$, equivalent to $\left.0.005 \mu \mathrm{M}\right)$. Although not statistically significant, this finding resembles previous data reporting a beneficial effect of certain cations, mainly $\mathrm{K}^{+}$(10 to $20 \mathrm{mM}$; Baloun \& Morse 1984, Yool et al. 1986, Pechenik \& Gee 1993) but also $\mathrm{Cu}^{2+}$ (1.6 to $4.7 \mu \mathrm{M}$; Nell $\&$ Holliday 1986), for settlement and metamorphosis of some bivalve and gastropod larvae.

Acknowledgements. We thank Dr D. Cossa and J. Sanjuan for analysing the mercury samples and D. Morgans for editing in kind the English manuscript. R.B. was supported by a postdoctorate Fellowship from the Consellería de Educación e Ordenación Universitaria (Galician Government) during the course of the study.

\section{LITERATURE CITED}

Akberali, H. B., Trueman, E. R. (1985). Effects of environmental stress on marine bivalve molluscs. Adv, mar. Biol. 22 101-198

Amiard-Triquet, C. (1983). Les tests de toxicité aiguë en milieu aquatique: méthodologie, standardisation, inter- 
prétation, limites d'application. Océanis 9(6): 451-463

Armstrong, D. A., Millemann, R. E. (1974). Effects of the insecticide Sevin and its first hydrolytic product, 1-naphthol, on some early developmental stages of the bay mussel Mytilus edulis. Mar. Biol. 28: 11-15

Baloun, A. J., Morse, D. E. (1984). Ionic control of settlement and metamorphosis in larval Haliotis rufescens (Gastropoda). Biol. Bull. 167: 124-138

Beaumont, A. R., Budd, M. (1984). High mortality of the larvae of the common mussel at low concentrations of tributyltin. Mar. Pollut. Bull. 15(11): 402-405

Brereton, A., Lord, H., Thornton, I., Webb, J. S. (1973). Effect of zinc on growth and development of larvae of the Pacific oyster Crassostrea gigas. Mar. Biol. 19: 96-101

Calabrese, A., Collier, R. S., Nelson, D. A., MacInnes, J. R. (1973). The toxicity of heavy metals to embryos of the American oyster Crassostrea virginica. Mar. Biol. 18: 162-166

Calabrese, A., Maclnnes, J. R., Nelson, D. A., Miller, J. E. (1977). Survival and growth of bivalve larvae under heavy-metal stress. Mar. Biol. 41: 179-184

Calabrese, A., Nelson, D. A. (1974). Inhibition of embryonic development of the hard clam, Mercenaria mercenaria, by heary metals. Bull environ. Contam. Toxicol. 11(1): 92-97

Chapman, P. M., Long, E. R. (1983). The use of bioassays as part of a comprehensive approach to marine pollution assessment. Mar. Pollut. Bull. 14(3): 81-84

Chapman, P. M., Morgan, J. D. (1983). Sediment bioassays with oyster larvae. Bull. environ. Contam. Toxicol. 31 $438-444$

Connor, P. M. (1972). Acute toxicity of heavy metals to some marine larvae. Mar. Pollut. Bull. 3(12): 190-192

Coon, S. L., Bonar, D. B., Weiner, R. M. (1986). Chemical production of cultchless oyster spat using epinephrine and norepinephrine. Aquaculture 58: 255-262

Cossa, D., Courau, P. (1990). An international intercomparison exercise for total mercury in seawater. Appl. Organometal. Chem. 4: 49-54

Cossa, D., Noël, J. (1987). Concentrations of mercury in near shore surface waters of the Bay of Biscay and in the Gironde Estuary. Mar. Chem. 20: 389-396

Cossa, D., Thibaud, Y., Roméo, M., Gnassia-Barelli, M. (1990). Le mercure en milieu marin, biogéochimie et écotoxicologie. Rapports scientifiques et techniques de I'IFREMER, No. 19. IFREMER, Brest

Davis, H.C., Hidu, H. (1969). Effects of pesticides on embryonic development of clams and oysters and on survival and growth of the larvae. Fish. Bull. U.S. 67(2): 393-404

Gill, G. A., Fitzgerald, W. F. (1987). Picomolar mercury measurements in seawater and other materials using stannous chloride reduction and two-stage gold amalgamation with gas phase detection. Mar. Chem. 20: 227-234

Granmo, A. (1972). Development and growth of eggs and larvae of Mytilus edulis exposed to a linear dodecylbenzenesulphonate, LAS. Mar. Biol. 15: 356-358

Hayes, W. J. (1991). Dosage and other factors influencing toxicity. In: Hayes, W. J., Laws, E. R. (eds.) Handbook of pesticide toxicology, Vol 1 Academic Press, San Diego, p. 39-105

His, E., Maurer, D. (1988). Shell growth and gross biochemical composition of oyster larvae (Crassostrea gigas) in the field. Aquaculture 69: 185-194

His, E., Robert, R. (1980). Action d'un sel organo-métallique, l'acétate de tributyl-étain sur les oeuts et les larves D de Crassostrea gigas (Thunberg). Comm. Meet. int. Counc. Explor. Sea C.M.-ICES/F: 27

His, E., Robert, R. (1981). Effects of copper chloride on the eggs and D-larvae of Crassostrea gigas (Thumberg). Pre- liminary results. Comm. Meet. int. Counc. Explor. Sea C.M.-ICES/F: 43

His, E., Robert, R. (1982). Le danger des traitements par le sulfate de cuivre en zone conchylicole: toxicité vis-à-vis des oeufs et des jeunes larves de Crassostrea gigas. Revue Trav. Inst. (scient. tech.) Pêch. marit. 45: 117-125

His, E., Robert, R. (1983). Développement des véligerès de Crassostrea gigas dans le bassin d'Arcachon. Etudes sur les mortalités larvaires. Revue Trav. Inst. (scient. tech.) Pêch. marit. 47: 63-88

His, E., Robert, R. (1986). Utilisation des élevages larvaires de Crassostrea gigas en écotoxicologie marine. Haliotis 15: $301-308$

His, E., Seaman, M. N. L. (1993). Effects of twelve pesticides on larvae of oysters (Crassostrea gigas) and two species of unicellular marine algae (Isochrysis galbana and Chaetoceros calcitrans). Comm. Meet. int. Counc. Explor. Sea C.M.-ICES/E: 22

Hrs-Brenko, M., Claus, C., Bubic, S. (1977). Synergistic effects of lead, salinity and temperature on embryonic development of the mussel Mytilus galloprovincialis. Mar. Biol. 44: $109-115$

Johnson, M. W., Gentile, J. H. (1979). Acute toxicity of cadmium, copper and mercury to larval American lobster Homarus amenicanus. Bull. environ. Contam. Toxicol. 22: 258-264

Lapota, D., Rosenberger, D. E., Platter-Rieger, M. F., Seligman, P. F. (1993). Growth and survival of Mytilus edulis larvae exposed to low levels of dibutyltin and tributyltin. Mar. Biol. 115: 413-419

Laughlin, R. B., Gustafson, R., Pendoley, P. (1988). Chronic embryo-larval toxicity of tributyltin (TBT) to the hard shell clam Mercenaria mercenaria. Mar. Ecol. Prog. Ser. 48: 29-36

Martin, M., Osborn, K. E., Billig, P., Glickstein, N. (1981). Toxicities of ten metals to Crassostrea gigas and Mytilus edulis embryos and Cancer magister larvae. Mar. Pollut. Bull. 12(9): 305-308

McFadzen, I. R. B. (1992). Growth and survival of cryopreserved oyster and clam larvae along a pollution gradient in the German Bight. Mar. Ecol. Prog. Ser. 91:215-220

Nell, J. A., Holliday, J. E. (1986). Effects of potassium and copper on the settling rate of Sydney rock oyster (Saccostrea commercialis) larvae. Aquaculture 58: 263-267

Nelson, D. A., Calabrese, A., Maclnnes, J. R. (1977). Mercury stress on juvenile Bay scallops, Argopecten irradians, under various salinity-temperature regimes. Mar. Biol. 43: 293-297

Nelson, D. A., Calabrese, A., Nelson, B. A., Macinnes, J. R., Wenzloff, D. R. (1976). Biological effects of heavy metals on juvenile Bay scallops, Argopecten irradians, in shortterm exposures. Bull. environ. Contam. Toxicol. 16(3): $275-282$

Okubo, K., Okubo, T (1962). Study on the bio-assay method for the evaluation of water pollution. II. Use of the fertilized eggs of sea urchins and bivalves. Bull. Tokai reg. Fish. Res. Lab. 32: 131-140

Pechenik, J. A., Gee, C. C. (1993). Onset of metamorphic competence in larvae of the gastropod Crepidula fornicata L. J. exp. mar. Biol. Ecol. 112: 27-38

Phelps, H. L., Warner, K. A. (1990). Estuarine sediment bioassay with pediveliger larvae (Crassostrea gigas). Bull. environ. Contam. Toxicol. 44: 197-204

Piyan, B. T., Law, A. T., Cheah, S. H. (1985). Toxic levels of mercury for sequential larval stages of Macrobrachium rosenbergii (De Man). Aquaculture 46: 353-359

Robert, R., His, E., Maurer, D. (1986). Toxicité d'un 
désherbant, l'atrazine-simazine, sur les jeunes stades larvaires de Crassostrea gigas et sur deux algues fourrages, Isochrysis aff. galbana et Chaetoceros calcitrans. Haliotis 15: 319-325

Roberts, M. H. (1987). Acute toxicity of tributyltin chloride to embryos and larvae of two bivalve mollusks, Crassostrea virginica and Mercenaria mercenaria. Bull. environ. Contam. Toxicol. 39: 1012-1019

Sharp, J. R., Neff, J. M. (1980). Effects of the duration of exposure to mercuric chloride on the embryogenesis of the estuarine teleost, Fundulus heteroclitus. Mar. environ. Res. 3: 195-213

Shealey, M. H., Sandifer, P. A. (1975). Effects of mercury on survival and development of the larval grass shrimp Palaemonetes vulganis. Mar. Biol. 33: 7-16

Sigler, M., Leibovitz, L. (1982). Acute toxicity of oil and bilge cleaners to larval American oysters (Crassostrea virginica). Bull. environ. Contam. Toxicol. 29: 137-145

Sokal, R. R., Rohlf, F. J. (1981). Biometry, W. H. Freeman, San Francisco

Swartz, R. C. (1989). Marine sediment toxicity tests. In: Contaminated marine sediments - assessment and remediation. Committee on contaminated marine sediments, Marine Board, Commission on engineering and technical systems, National Research Council. National Academy Press, Washington, DC, p. 115-129

Thain, J. E (1983). The acute toxicity of bis (tributyltin) oxide to the adults and larvae of some marine organisms. Comm. Meet. int. Coun. Explor. Sea C.M.-ICES/E:13

Thain, J. E. (1984). Effects of mercury on the prosobranch

This article was submitted to the editor mollusc Crepidula fornicata: acute lethal toxicity and effects on growth and reproduction of chronic exposure. Mar. environ. Res. 12: 285-309

Thain, J. (1992). Use of the oyster Crassostrea gigas embryo bioassay on water and sediment elutriate samples from the German Bight. Mar. Ecol. Prog. Ser. 91: 211-213

Tian-yi, C., McNaught, D. C. (1992). Toxicity of methylmercury to Daphnia pulex. Bull. environ. Contam. Toxicol. 49: $606-612$

Walne, P. R. (1970). Present problems in the culture of the larvae of Ostrea edulis. Helgoländer Meeresunters. 20: $514-525$

Watling, H. R. (1982). Comparative study of the effects of zinc, cadmium and copper on the larval growth of three oyster species. Bull. environ. Contam. Toxicol. 28: 195-201

Wiederholm, T., Wiederholm, A. M., Milbrink, G. (1987). Bulk sediment bioassays with five species of fresh-water oligochaetes. Wat. Air Soil Pollut. 36: 131-154

Wisely, B., Blick, R. A. P. (1967). Mortality of marine invertebrate larvae in mercury, copper and zinc solutions. Aust. J. mar. Freshwat. Res. 18: 63-72

Wong, C. K., Chu, K. H., Tang, K. W., Tam, T. W., Wong, L. J. (1993). Effects of chromium, copper and nickel on survival and feeding behaviour of Metapenaeus ensis larvae and postlarvae (Decapoda: Penaeidae). Mar. environ. Res. 36: $63-78$

Yool, A. J., Grau, S. M., Hadfield, M. G., Jensen, R. A., Markell, D. A., Morse, D. E. (1986). Excess potassium induces larval metamorphosis in four marine invertebrate species. Biol. Bull. 170: 255-266

Manuscript first received: March 31, 1994

Revised version accepted: August 10, 1994 